\title{
Measuring and Forecasting Chinese Domestic Supply and Demand for Grain Sorghum
}

\author{
Shuguo Yang1, Jaime Malaga² \\ ${ }^{1}$ College of Economics \& Management, Heilongjiang Bayi Agricultural University, Daqing, China \\ ${ }^{2}$ Department of Agricultural and Applied Economics, Texas Tech University, Lubbock, Texas \\ Email: rhwysg@163.com, Jaime.malaga@ttu.edu
}

How to cite this paper: Yang, S.G. and Malaga, J. (2020) Measuring and Forecasting Chinese Domestic Supply and Demand for Grain Sorghum. Agricultural Sciences, 11, 71-87.

https://doi.org/10.4236/as.2020.111005

Received: August 11, 2019

Accepted: January 3, 2020

Published: January 6, 2020

Copyright $\odot 2020$ by author(s) and Scientific Research Publishing Inc. This work is licensed under the Creative Commons Attribution-NonCommercial International License (CC BY-NC 4.0).

http://creativecommons.org/licenses/by-nc/4.0/

\begin{abstract}
In the past 5 years, the use of sorghum as substitutes for corn for feed in China has increased rapidly. Most of the recent growth of demand in sorghum has mainly been met by imported sorghum. Because sorghum is a minor crop and only shares a very small proportion of the grain production in China, few studies have examined domestic demand and supply of sorghum in China. Both China's producers and other sorghum import countries can benefit from forecasts of China's domestic supply and demand for sorghum.
\end{abstract}

\section{Keywords \\ Sorghum, China, Demand and Supply}

\section{Introduction}

China has been showing an impressive growth in consumption of animal protein which has resulted in a rapidly increasing derived demand for feed grains. The demand for feed grain in China would increase with growing income and the change of dietary structure, needing more meat, eggs and milk in the future. Ran \& Wang (2017) indicated that the demand of feed grain would reach 215.96 million tons in China in 2020. In order to release the pressure of feed grain demand, ways, including enlarging production of feed grain and importing feed grain moderately, were put forwarded [1].

In China, feed grain mainly includes corn, rice, wheat, sorghum, barley, and so on. Corn is the major feed grain and accounts for up to $60 \%$ of feed grain composition [2]. Because corn is subject to tariff rate quota (TRQ) and the expensive domestic price, China began to import a large amount sorghum, barley and Distillers Dried Grains with Solubles (DDGS), and so on, as substitutes for corn for feed, especially sorghum, since its nutrition is similar to that of corn. 
Since 2013, China has shown an explosive growth rate of sorghum imports for feed use and has become the largest importer in the world since 2014. The imports of sorghum in 2015 reached record highs-10.70 million metric tons (MMT), accounting for $80 \%$ of the world total exports and $79.60 \%$ of the total China sorghum supply. This notable import demand of sorghum has attracted great attention from sorghum exporting countries, especially the U.S., which has become the largest market for Chinese-imported sorghum since 2014. More than $80 \%$ of U.S.-exported sorghum was sent to China from 2014 to 2018, and accounting for $88 \%$ of Chinese-imported sorghum in 2018.

A large amount of imported sorghum is mainly used for feed to substitute for corn due to low price and low tannin content of imported sorghum. With the further research on the nutritional value of sorghum, imported sorghum may be used more for feed production [3]. The proportion of sorghum substitution reached 40\% - 50\% for duck feed in 2014 and 10\% - 20\% in feed enterprises in 2015 in southern China [4]. In southern China, the proportion of sorghum for feed varies from $20 \%$ to $40 \%$ according to the formula in pig and duck farms ${ }^{1}$.

China is one of the major sorghum producers in the world. Domestic sorghum production was about 3.00 million metric tons every year from 2013 to 2017, which was mainly used for liquor (baijiu), sugar and food [3]. Because most sorghum is brown sorghum with high tannin content, it affects the digestion and absorption of other nutrients by animals [3]. Production for sorghum has increased since 2012. The production reached 3.2 million metric tons and planted area reached 675 thousand hectare in 2017 because of China's Agricultural Structure Adjustment policy.

Given the fact that corn is still a grain in Chinese "95\% self-sufficiency" program, corn imports are limited, and the excess demand for feed grains has translated into demand for sorghum, its closest substitute. Will sorghum demand increase driven by demand for substitute? Given another fact of limited land resources of China, will Chinese sorghum production increase affected by policies?

This research is to estimate the potential expansion of Chinese sorghum supply at a regional level and with alternative technology improvements. At the same time, the study aims at a more specific estimation of Chinese domestic demand by types of use (food, feed, industrial). The study will primarily use Chinese data collected by Heilongiiang Bayi Agricultural University. Final results will be used to complement previous models of Chinese import demand estimated by our Department and to forecast Chinese sorghum potential demand with the increasing of domestic productivity and Chinese price policies.

\section{Domestic Demand and Supply of Sorghum: Past and Present}

\subsection{Domestic Demand}

Credible information is hard to find to help answer how much domestic demand

${ }^{1}$ Source: http://www.yumi.com.cn/html/2014/06/20140616233528155688.html, 2014-06-16. 
of sorghum. There are no authoritative and reliable statistics about the demand of sorghum in China. So we use USDA data to understand the demand of sorghum in the past and present.

According to USDA data, there have been three periods of rising sorghum domestic consumption since the 1960s in China, which are 1960/61-1975/76, 1990/91-1994/95 and 2010/11-2014/15, and three periods of falling sorghum consumption, which are 1976/77-1989/90, 1996/97 and 2015/16-2017/18.

Sorghum consumption increased from 4.47 million metric tons in the early 1960 s to 10.85 million metric tons in $1975 / 76$, an average of $6.55 \%$ a year. It then declined to 4.17 million metric tons in 1989/90, then recovered to 6.36 million metric tons in 1994/95, and then declined. Sorghum consumption reached 1.90 million metric tons in 2009/10, the lowest record in history, and then increased. Sorghum consumption peaked and reached 12.90 million metric tons in $2014 / 15$, and then declined. In 2017/18, sorghum consumption declined to 7.80 million metric tons (Figure 1).

In China, sorghum is widely used for food, liquor and vinegar brewing, feed, ethanol for biodiesel, and others. Sorghum was mainly consumed as food in China before the 1980s, and its use in the production of hard liquor increased after the 1980s [5]. Since the 1980s, sorghum products have undergone the process from food consumption to comprehensive utilization, such as brewing, feeding and processing.

The FSI consumption of sorghum once had an $87 \%$ share of the total domestic sorghum consumption in 1962/63. Feed consumption exceeded FSI consumption and had a $64 \%$ share of the total domestic sorghum consumption in 1983/84. According to the cost data, seed consumption accounted for about $9 \%$ of the total sorghum consumption in 1984. From the mid-1980s to the early 2010s, sorghum was mainly used for FIS consumption, accounting for $95 \%$ of

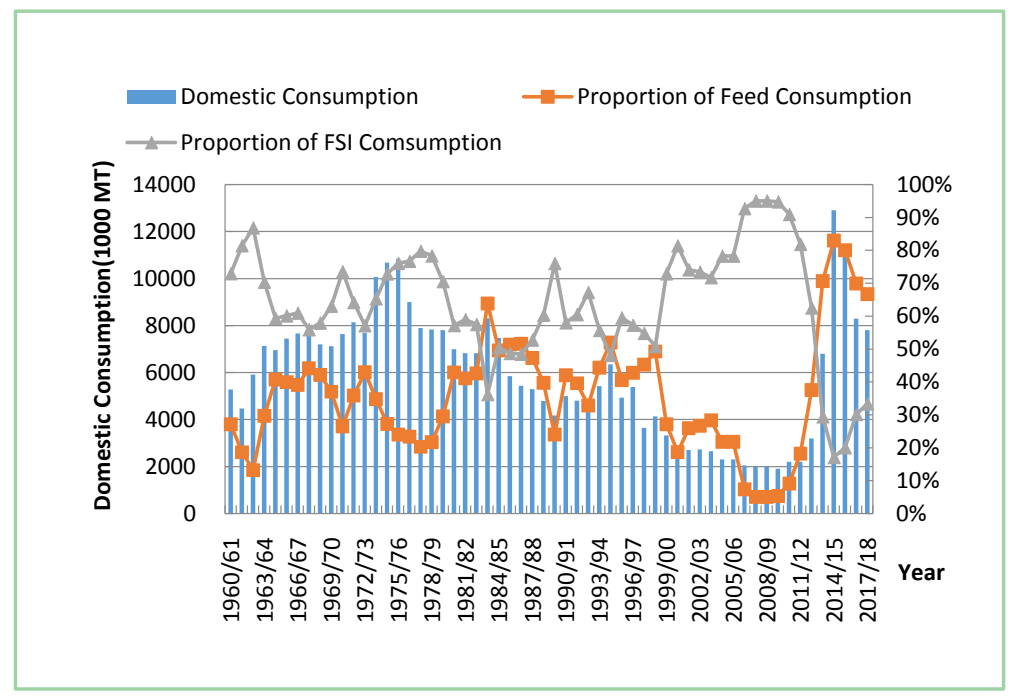

Figure 1 Sorghum domestic consumption in china. FSI: Food, Seed \& Industrial Consumption. Source: USDA. 
the total sorghum consumption in 2007/08-2008/09, especially for liquor brewing. After 2010, FSI consumption was declining due to a large slowdown in hard liquor production, which was likely related to the government's anti-corruption, stated in 2012 [2]. Feed has been the main consumption of sorghum since $2013 / 14$ and accounted for $83 \%$ of the total domestic sorghum consumption in $2014 / 15$, the highest in history, and then slowly declined. In 2017/18, feed consumption accounting for $67 \%$ of the total sorghum consumption (Figure 1).

\subsection{Domestic Supply}

Chinese consumption of sorghum has been mainly met by increased domestic supply before 2013 and imports of sorghum have been minimal. Indeed, from 1979 to 2011, China has been a net exporter of sorghum. Exceptions are 1983 and 2010. During these years, China imported a small amount of sorghum. After 2011, China became a net importer of sorghum. China's sorghum imports have risen dramatically since 2013, and China became the largest importer in the world in 2014, with sorghum imports sharing $68.43 \%$ of the world's total sorghum imports. Sorghum imports reached record highs in 2015, 10.70 million metric tons, sharing $79.60 \%$ of the total China sorghum supply and accounting for $79.5 \%$ of the world total sorghum imports. Sorghum imports began to decline after 2015. In 2017, sorghum imports declined to 5.06 million metric tons (Trade map).

China has a long history of planting sorghum [2] [6]. Since the mid- $20^{\text {th }}$ century, there have been several periods of dramatic sorghum production surges in China. Three periods of rising sorghum production are the early 1950s, 1960s to the mid-1970s, and 2010s, and two periods of falling sorghum production are 1953-1960 and 1975-2009.

The production quantity of sorghum increased to 11.09 million metric tons in 1952, sharing $6.77 \%$ of the total grain production. In the same period, the area planted increased to 9.39 million hectares, sharing $7.57 \%$ of the total grain planted area. Yield of sorghum was $1182 \mathrm{Kg} / \mathrm{Ha}$. In this period, the average annual growths of production, area, and yield were $18 \%, 1.70 \%$, and $16.03 \%$, respectively. Obviously, yield of sorghum contributed to the production more than did area. Land reform from 1950 to 1952 boosted farmers' enthusiasm for production and promoted the development of grain production, including sorghum.

The production quantity of sorghum has declined since 1953. In 1960, it was 3.44 million metric tons, an average decrease of $13.60 \%$ a year, of which $10 \%$ came from the drop in area and 3.60\% came from yield. From 1959 to 1961, the Great Leap Forward and the policy of sacrificing agriculture for industrial development resulted in reduction of grain area, coupled with three years of natural disaster reducing grain yield. Sorghum planted area decreased to 3.95 million hectares, and sorghum yield reached $871 \mathrm{Kg} / \mathrm{Ha}$ in 1960, both lowest record since 1950 . 
Production for sorghum started to recover slowly in 1961, escalated in 1974, and peaked, reaching record highs, 11.38 million metric tons, in 1974. Nevertheless, the increase of area planted for sorghum was not as dramatic as that of production. Area planted for sorghum peaked and reached 6.72 million hectares in 1963 , then declined slowly. Yield of sorghum raised to $2165 \mathrm{Kg} / \mathrm{Ha}$ in 1974 , 2.49 times that of 1960, and was caused by increased investment in agriculture by the government, such as in irrigation, pesticide, and fertilizer.

Production for sorghum began to decline rapidly after 1975 and reached a record low, 1.68 million metric tons in 2009, which was mainly due to the reduction of area. In 2008, area planted for sorghum reached a record low, 0.49 million hectares. In this period, the decline of sorghum consumption was the main reason affecting sorghum production. In 2008, the government placed a policy called the "government temporary reserve program" on corn, soybean, and cotton, and this policy encouraged the production of these crops. Due to the limitation of farmland, the area of sorghum without policy support has been greatly reduced. Although yield of sorghum reached $3749 \mathrm{Kg} / \mathrm{Ha}$, this was lower than the yield of corn, rice and wheat (Figure 2). In general, sorghum production has declined (Figure $3 \&$ Figure 4).

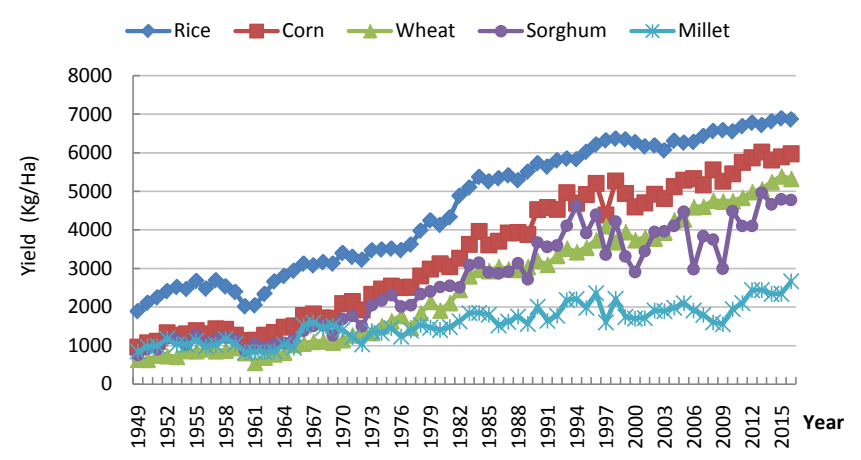

Figure 2. Different crops yield in china from 1949 to 2016. Source: National Bureau of Statistics.

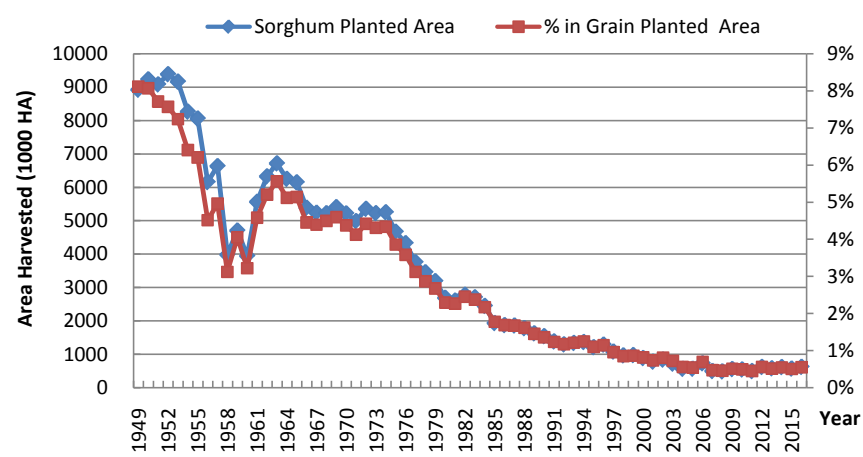

Figure 3. Sorghum area harvested in china from 1949 to 2016. Source: National Bureau of Statistics. 


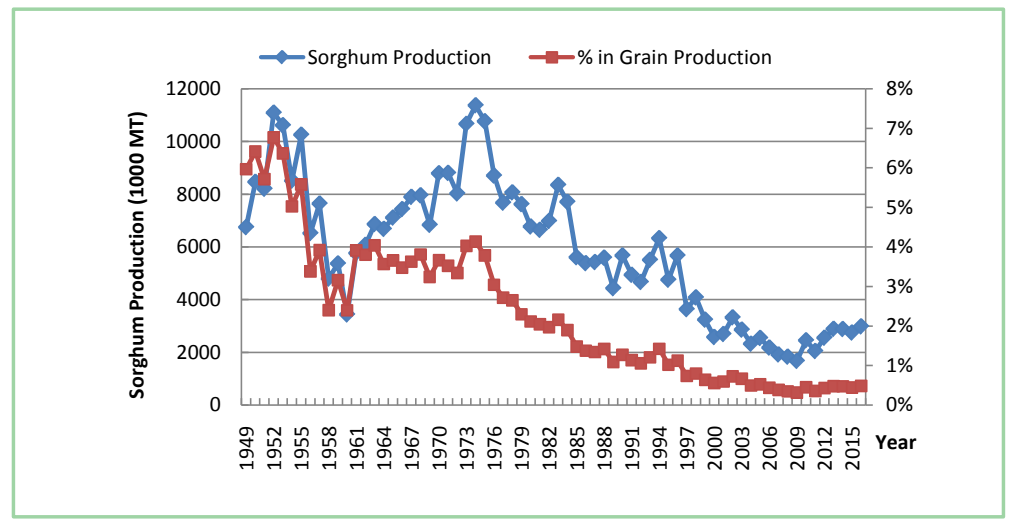

Figure 4. Sorghum production in china from 1949 to 2016. Source: National Bureau of Statistics.

Production for sorghum has recovered since 2010, reaching 2.98 million metric tons, and the area reached 0.63 million hectare in 2016. In the past ten years, production has been mainly caused by the yield which has increased to 4000 $\mathrm{Kg} / \mathrm{Ha}$ since 2010 and reached $4774 \mathrm{Kg} / \mathrm{Ha}, 1.59$ times that of 2009.

Sorghum is widely planted in China except in Shanghai, Zhejiang, Qinghai, and Xizang province. Sorghum production is divided into four cultivation areas. Spring sowing and early-maturing areas include Heilongjiang, Jilin, Inter Mongolia and Chengde of Hebei, downstream of Zhangjiakou, north of Shanxi and Shanxi, the arid area of Ningxia, mid and Hexi region of Gansu and north of Xinjiang, and so on. Spring sowing and late-maturing areas include most of Liaoning, Hebei, Shanxi, Shaanxi, Beijing, Tianjin, the Huanghuai region of Ningxia province, east and south of Gansu, and south and north of Xinjiang, which are the main sorghum areas in China. Spring and summer sowing areas include Shandong, Jiangsu, Henan, Anhui, Hubei, and part of Hebei. South areas include south of central China, South and Southwest [7].

There are four advantaged areas of sorghum production. Sorghum in the Northeast, about 0.53 - 0.67 million hectares, is mostly used for liquor, and part is used for sorghum rice. Sorghum in North and Northeast, about 0.33 million hectares, is mainly used for liquor and feed. Sorghum in the Southwest, about 0.13 million hectares, is entirely used for liquor. The Yellow River to the Yangtze River Basin, were the main sorghum areas previously and are now the potential area of the sweet sorghum used for ethanol [8].

In the early 1950s, Liaoning, Shandong, Hebei, Jilin, and Henan were the main sorghum production areas. Since the 1980s, planting areas have changed from good production conditions to drought, semi-drought, and saline-alkali production conditions. Now, the main production areas, the Northeast, the plain of Northwest and North, plant more than two third of all China's sorghum, especially in the Northeast, which includes Jilin, Inner Mongolia, Liaoning, and Heilongjiang provinces. Northeast 's sorghum area and production accounted for $50 \%$ and $63 \%$ of total China sorghum area and production in 2016, respectively. 
The highest proportion was more than $70 \%$ in 2006. The top six provinces/regions are Jilin, Inner Mongolia, Sichuan, Liaoning, Guizhou, and Heilongjiang, as of 2016 (Figure 5). The change of the main areas of sorghum production is mainly because sorghum, as one of the minor grain crops, cannot take fertilized land from the major grain crops.

\section{Domestic Demand and Supply of Sorghum: Previous Estimations and Projections}

Research on China's domestic sorghum supply is lacking. According to "Report on Operation Situation and Development Analysis of Sorghum Industry in China" (2017), the main planting regions of sorghum in recent years are concentrated in three provinces, Heilongjiang, Jilin, and Liaoning, and one region, Inner Mongolia in Northeast of China, and the planting area in these regions has gradually increased in the last three years. Because sorghum is included in miscellaneous cereals in China, scholars mostly analyzed the current situation and trend from the perspective of miscellaneous cereal production in different production regions.

However, the special research of China's domestic sorghum demand is scattered, lacks objective statistics, and always exists in projections of the total feed grain.

The demand of sorghum was increasing. Firstly, the demand of liquor sorghum was increasing. According to Economic Daily, there are hundreds of large distilleries which are the big consumers of sorghum and consume sorghum 1.00 1.50 MMT per year. Small distilleries consume sorghum about 1.00 MMT per year. So domestic distilleries need 2.50 - 2.80 MMT of sorghum per year. Secondly, the demand of vinegar-making sorghum is also increasing. The demand of sorghum used for vinegar is about $0.70-0.80$ MMT per year. Thirdly, the

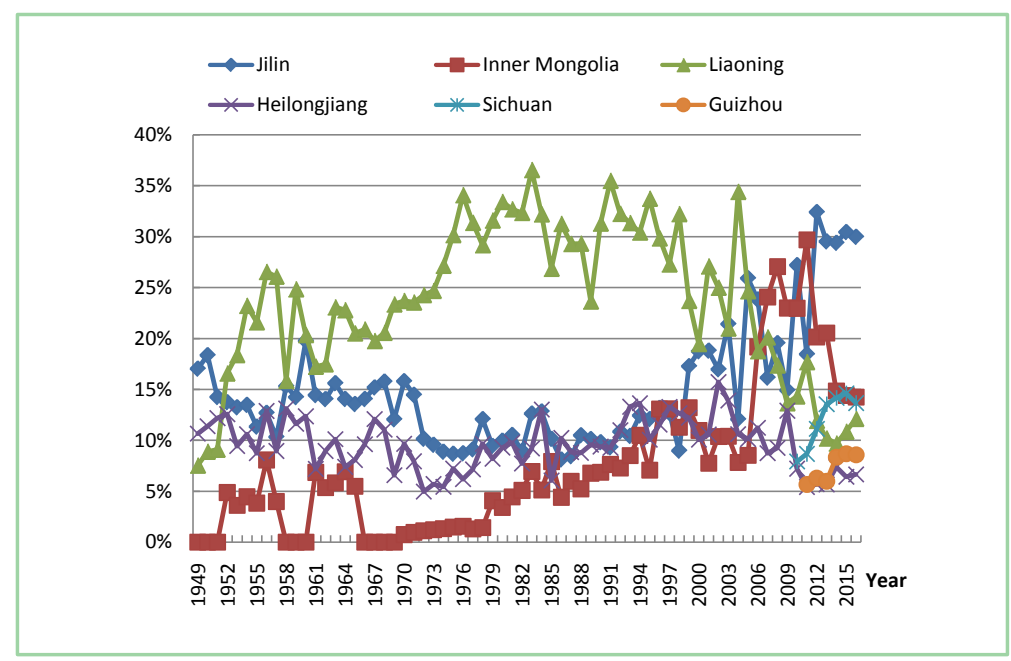

Figure 5. Proportion of sorghum production of main regions in china. Source: National Bureau of Statistics. 
demand of sorghum used for feed is increasing with the development of stockbreeding in the process of Agricultural Structure Adjustment in China. Sweet sorghum is an excellent forage crop with fresh and tender stalks, rich in sugar, soft leaves and good palatability in China. Sweet sorghum has a long history of being used for feed in China. But in recent years, it has been widely planted for feed [9]. According to the survey and estimation of typical feed formulations and feed sources in some provinces, sorghum used for feed accounted for 50\% of sorghum production based on the grain output [10]. In addition, sorghum has great potential for ethanol with the increase of energy consumption derived by automotive industry [8].

Sweet sorghum used for ethanol has a great potential for growth in China. Since 2002, China has decided to use fuel ethanol in automobiles. China began to implement the Bioenergy Law in January 2006 and China held a conference on bioenergy in August 2006, which proposed to vigorously develop China's bioenergy. Considering food security, the principle is that non-grain substitution should be adhered to in the development of bioenergy in China. So the government encourages the cultivation of energy crops on marginal, non-arable land. The biological characteristics of sweet sorghum are in line with the principle of developing bioenergy in China. Some data showed that the yield of straw and seed would reach 60 tons/ $\mathrm{Ha}$ and $1500 \mathrm{Kg} / \mathrm{Ha}$, respectively, if sweet sorghum was planted in the saline-alkali soil and 16 tons of straw may produce 1 ton of ethanol. Experiments were conducted in Heilongjiang, Inner Mongolia, Shandong, Xinjiang, and Tianjin [11]. The experiment by the Institute of Botany, the Chinese Academy of Sciences, showed that per hectare of sweet sorghum could produce 6150 litres of ethanol [12].

There are two viewpoints on the substitution of sorghum for corn as feed in the future. One view is that sorghum may partly replace corn, not completely. Moreover, the substitution of sorghum for corn is due to the rising price of corn, which can be used as a regulation of marketing change, but not a long term solution. The view holds that the function of corn in feed is irreplaceable. One reason is that tannin which is an anti-nutritional factor in sorghum affects the conversion and metabolic energy value. Another reason is that it is not realistic to develop tannase to reduce the effects of tannin on animals because of the high cost. Another view is that sorghum replacing corn is just a trend. One reason is that the problem of anti-nutritional factors can be solved by technology, such as sorghum peeling, ripening, adding enzymes, etc. Another reason is that the cost can be saved RMB 200 yuan per ton if sorghum accounts for 50\% of the pig feed. As long as the price of sorghum is 100 yuan/ton lower than that of corn, sorghum has a cost advantage. At present, the price of sorghum is about $300-400$ yuan per ton lower than that of corn $^{2}$.

According to the estimation of USDA, China's domestic consumption of sorghum would continue to decline in 2018/2019 and reach 5.50 million tons, ${ }^{2}$ Source: http://www.feedtrade.com.cn/technology/nutrition/ingredient/2015-01-16/2015632.html, 2015-01-16. 
$28.49 \%$ lower than in $2017 / 2018$. Feed consumption would decline to 2.80 million tons, accounting for $50.90 \%$ of the total domestic consumption, $46.15 \%$ lower than in $2017 / 2018$. FSI consumption would increase to 2.70 million tons, $3.85 \%$ higher than in 2017/2018. China's domestic sorghum production would increase to $3.45 \mathrm{MMT}$ in 2018, 7.81\% higher than in 2017 (USDA).

Li et al. (2010) forecasted that feed grain in China would increase to 113.07 MMT in 2020. OECD-FAO predicted that in China, maize used for feed and domestic production will increase to 171.39 MMT and 250.63 MMT in 2027, respectively [10]. Conversely, Yang et al. (2017) forecasted that China's domestic corn production would decline and the demand of feed grain would increase rigidity and develop to quality and efficiency from 2016 to 2020, which would cause the increase of feed grain imports [13]. Ran et al. (2017) predicted that the demand of feed cereal would increase to 215.95 MMT derived by the demand of meat, eggs, and milk. But these projections didn't include the sorghum demand and supply in China [1].

\section{Domestic Demand and Supply of Sorghum: Measuring and Forecasting}

\subsection{Measuring on Domestic Supply of Sorghum}

China's sorghum production is determined by sorghum area and sorghum yield. In China, self-sufficiency of the main grains (rice, wheat, and corn) is the most core task in the development of the planting industry. So the amount of land is limited for expanding sorghum production. But at present, with the development of breeding, cultivation, and other technology, there is the potential to improve sorghum yield in China, and it is possible to achieve a steady and slight increase in total sorghum production.

On the one hand, regarding of planted area, it is hard to increase substantially the planted area of sorghum in the whole country. The area constraints are affected by the tight balance of supply and demand of the three major staple grains, the core goal of food security and farmers' rational choice based on comparative benefits. But sorghum planted in the northeast, including Heilongjiang, Jilin, Liaoning, and Inner Mongolia, and the northwest, including Shaanxi, Gansu, Ningxia, Xinjiang, and the provinces, including Hebei, Shanxi, Guangxi, Guizhou, Yunnan, are likely to expand due to the policy of planting structure adjustment. National Planning for Planting Structure Adjustment (2016-2020) drawn up by the Ministry of Agriculture in 2016 points out that the planted area of potato and minor grains will reach about 15.33 million hectares by 2020 through reducing appropriately the area of corn in the "sickle bend" and replacing drought-tolerant and barren-tolerant potatoes and minor grains. Guidelines for national minor grain crops production (2016) pointed out that sorghum planting area should be increased appropriately in high latitude regions, such as Hulunbuir in Inner Mongolia, Heihe and Qiqihar in Heilongjiang through rotation. They also state to moderately plant sorghum in other regions, such as Chi- 
feng, Tongliao, Xing'an League and the middle part of Inner Mongolia; Baicheng and Songyuan in Jilin; Chaoyang, Fuxin and Jinzhou in Liaoning; Shanxi; and Hebei. From the change of sorghum area in the main production regions in the past four years, it can be found that the sorghum planted area showed an increasing trend in these regions from 2015 to 2016 (Figure 6). However, in general, the potential growth of the sorghum planted area is limited. Moreover, sorghum area did not increase but decreased in 2017. According to the data from China's National Bureau of Statistics, the planted area of sorghum accounted for $0.30 \%$ of the total crop area in 2017. On the basis of this proportion, sorghum area was 499,000 hectares, 12,620 hectares lower than that in 2016, because China's National Bureau of Statistics has increased the area of corn, rice, and wheat based on the results of the Third National Agricultural Survey. It is difficult to analyze domestic sorghum supply using an econometrics model because the adjusted sorghum production data will be no longer released.

At present, the area for planting minor grains in China reached about 7.33 8.66 million hectares [14], and the sorghum area accounted for about $7 \%-9 \%$ of the total minor grains area. Area of potatoes in China reached 8.94 million hectares in 2016 (National Bureau of Statistics), assuming that even if the area of potatoes remains unchanged, the area of minor grains will reach only 7.41 million hectares. If the present proportion of $9 \%$ continues, then the area of sorghum will reach 666,630 hectares in 2020.

From the perspective of comparative crop benefits, income of sorghum in Heilongjiang Jianshan Farm was 515 Yuan/Ha less than that of corn in 2018 (Table 1). So sorghum area will not increase if farmers only consider the economic factor. Even though the profit of sorghum was higher than that of other crops in 2007 (Table 2), the area of sorghum has not increased significantly. So the comparative income is not the main reason for the change of sorghum area.

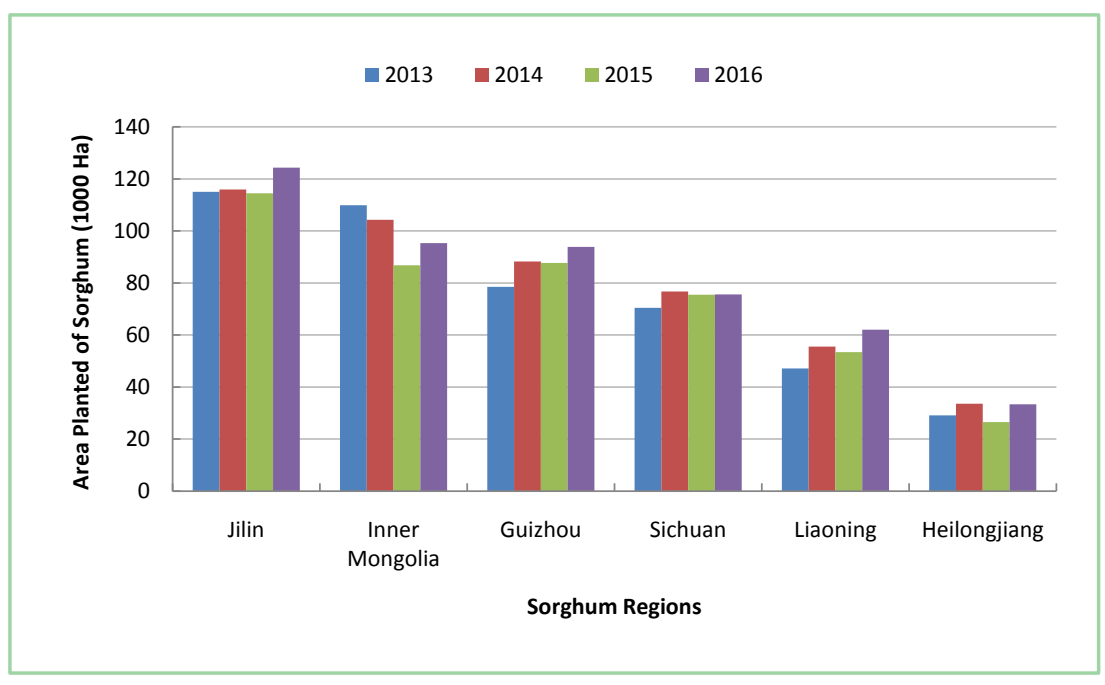

Figure 6. Change of sorghum area in main production regions from 2013 to 2016. Source: National Bureau of Statistics, China. 
Table 1. Cost and return of different crops of Heilongjiang Jinshan farm in 2018.

\begin{tabular}{cccccccc}
\hline Crops & $\begin{array}{c}\text { Yield }^{1} \\
\mathrm{Kg} / \mathrm{Ha}\end{array}$ & $\begin{array}{c}\text { Price } \\
\text { Yuan/Kg }\end{array}$ & $\begin{array}{c}\text { Gross Value } \\
\text { Yuan/Ha }\end{array}$ & $\begin{array}{c}\text { Cost } \\
\text { Yuan/Ha }\end{array}$ & $\begin{array}{c}\text { Return } \\
\text { Yuan/Ha }\end{array}$ & $\begin{array}{c}\text { Subsidy }^{2} \\
\text { Yuan/Ha }\end{array}$ & $\begin{array}{c}\text { Final Return } \\
\text { Yuan/Ha }\end{array}$ \\
\hline Sorghum & 6750 & 1.76 & 11,880 & 9500 & 2380 & 1091.55 & 3472 \\
Corn & 10,500 & 1.24 & 13,020 & 10,500 & 2520 & 1466.55 & 3987 \\
Soybean & 3000 & 3.76 & 11,280 & 8500 & 2780 & 5891.55 & 8672 \\
\hline
\end{tabular}

${ }^{1}$ The yield is lower than the normal level because Jianshan Farm a suffered frost disaster in 2018. ${ }^{2}$ Producer subsidies of soybean and corn were $4800 \mathrm{Yuan} / \mathrm{Ha}$ and $375 \mathrm{Yuan} / \mathrm{Ha}$ in Heilongjiang in 2018, respectively. Subsidy for farmland productivity protection for all grains was $1091.55 \mathrm{Yuan} / \mathrm{Ha}$.

Table 2. Cost and return of different crops in china in 2007.

\begin{tabular}{cccc}
\hline Crops & $\begin{array}{c}\text { Return } \\
\text { Yuan/Ha }\end{array}$ & $\begin{array}{c}\text { Subsidy } \\
\text { Yuan/Ha }\end{array}$ & $\begin{array}{c}\text { Final Return } \\
\text { Yuan/Ha }\end{array}$ \\
\hline Sorghum & 3351.60 & 376.50 & 3728.10 \\
Rice & 3125.70 & 415.35 & 3541.05 \\
Corn & 3012.30 & 324.00 & 3336.30 \\
Soybean & 2628.15 & 346.65 & 2974.80 \\
Millet & 2797.20 & 198.60 & 2995.80 \\
Wheat & 1879.50 & 371.55 & 2251.05 \\
\hline
\end{tabular}

Source: Compilation of Cost-Benefit Data of National Agricultural Products (2008).

On the other hand, from the perspective of sorghum yield, according to the USDA's data, China's sorghum yield reached $4790 \mathrm{~kg} / \mathrm{ha}$ in 2018, ranking second in the world, after Egypt. Historically, the highest yield of China's sorghum reached $4970 \mathrm{~kg} / \mathrm{Ha}$ in 2013. Technical guidance for sorghum production (2016-2018) from the National Agricultural Technology Extension Service Center played an important role in raising sorghum yield. Sorghum yield in Jilin, Heilongjiang, Liaoning and Sichuan is higher than that of the national average, and it reached $7200 \mathrm{~kg} / \mathrm{ha}, 5958 \mathrm{~kg} / \mathrm{ha}, 5829 \mathrm{~kg} / \mathrm{ha}$ and $5396 \mathrm{~kg} / \mathrm{ha}$ in 2016 , respectively. The highest yield in Jilin reached $7426 \mathrm{~kg} / \mathrm{ha}$ in 2013 (Figure 7). So China has some potential to increase its national average sorghum yield in the future.

Overall, based on these, sorghum production will be estimated to reach 4.00 MMT in 2020 if sorghum yield and area increase to $6000 \mathrm{~kg} / \mathrm{ha}$ and 666,630 hectares, respectively.

\subsection{Forecasting on Domestic Demand of Sorghum}

Despite the lack of data on sorghum consumption in China, we try to synthesize various factors to forecast and judge the sorghum demand by types of use (seed, food, feed, industrial), and then forecast the domestic demand of sorghum in China. Industry data showed that about $60 \%$ of sorghum is used for feed ${ }^{3}$. According to the data from "Report on Operation Situation and Development Analysis of Sorghum Industry in China", feed consumption accounted for $63.74 \%$ ${ }^{3}$ https://www.chyxx.com/industry/201806/647832.html, 2018-06-08. 


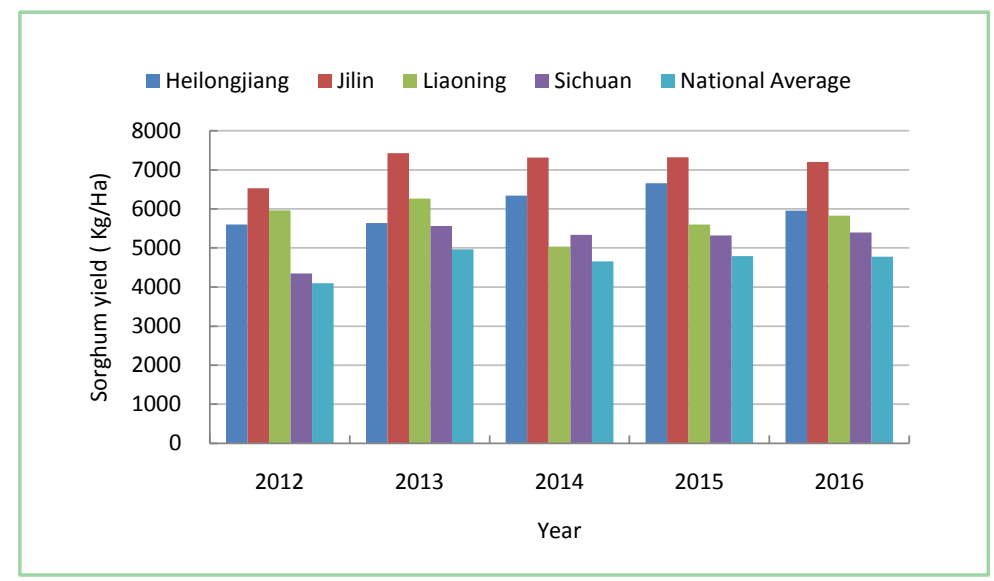

Figure 7. Sorghum yield in main sorghum production region. Source: National Bureau of Statistics, China.

of the total sorghum consumption in 2017, decreasing by $16 \%$ in 2016. Meanwhile, food consumption and industrial consumption increased by $1 \%$ and $15 \%$, respectively, and the data showed that the amount of imported sorghum for industrial consumption and food was predicted to reach 1,300,000 tons and accounted for about $25 \%$ of imported sorghum in 2017.

\subsubsection{Sorghum for Seed}

Demand of sorghum for seed can be calculated by the amount of seed consumption per unit area and sorghum planted area. The amount of seed consumption was about $30 \mathrm{~kg} / \mathrm{ha}$ from 2004 to 2007 and the area of sorghum is known. We can calculate that the amount of sorghum for seed demand was 146,400 212,100 tons, accounting for $0.77 \%-1.15 \%$ of the FSI consumption and $0.68 \%$ $0.98 \%$ of domestic consumption from 2004 to 2007 (Table 3).

The amount of seed consumption is $7.50-11.25 \mathrm{~kg} / \mathrm{ha}$ by manual sowing and $9.75-13.50 \mathrm{~kg} / \mathrm{ha}$ by mechanical sowing. So the amount of average seed consumption is $8.6-12.40 \mathrm{~kg} / \mathrm{ha}$. According to the survey, the amount of seed consumption is $10.50-13.35 \mathrm{~kg} / \mathrm{ha}$ by mechanical sowing in Heilongjiang Jianshan Farm in 2018. Based on these data and the previous estimated sorghum area in 2020, total seed demand can be forecasted to reach 5750 - 8250 tons in 2020 .

\subsubsection{Sorghum for Food}

In China, the crops rice, wheat, maize, soybean and potatoes are called major grains. Other crops, like sorghum, millet, oat, beans, and so on, are called miscellaneous grains. In recent years, with the improvement of people's living standard, the consumption of miscellaneous grains is increasing day by day. The $\mathrm{Di}$ etary Guidelines for Chinese Residents recommends eating 50 - 100 grams of miscellaneous grains a day, accounting for about one fifth of the total daily food intake, which can ensure the intake of vitamins, minerals and dietary fibers to avoid malnutrition. Nevertheless, the consumption of sorghum for food will only increase slightly, but not significantly. 
Table 3. Sorghum for seed in China from 2004-2007.

\begin{tabular}{ccccc}
\hline Year & 2004 & 2005 & 2006 & 2007 \\
\hline Seed $^{1}(\mathrm{Kg} / \mathrm{Ha})$ & 29.85 & 31.35 & 28.95 & 29.25 \\
Area $^{2}(1000 \mathrm{Ha})$ & 567.34 & 569.72 & 732.78 & 500.43 \\
Total Seed (1000 MT) & 16.94 & 17.86 & 21.21 & 14.64 \\
FSI Consumption ${ }^{3}(1000 \mathrm{MT})$ & 1850 & 1800 & 1850 & 1900 \\
Proportion of Seed & $0.92 \%$ & $0.99 \%$ & $1.15 \%$ & $0.77 \%$ \\
Domestic Consumption $^{3}(1000 \mathrm{MT})$ & 2475 & 2300 & 2175 & 2025 \\
Proportion of Seed & $0.68 \%$ & $0.78 \%$ & $0.98 \%$ & $0.72 \%$ \\
\hline
\end{tabular}

${ }^{1}$ Source: Compilation of Cost-Benefit Data of National Agricultural Products (2005-2008); ${ }^{2}$ Source: National Bureau of Statistics, China; ${ }^{3}$ Source: Conversion based on USDA data.

\subsubsection{Sorghum for Industrial Consumption}

In sorghum for FSI consumption, industrial consumption is the main consumption. The growth of FSI consumption mainly comes from the increase of industrial consumption because the proportion of food consumption and seed consumption is small. Sorghum for FSI consumption increased from 1.80 MMT in 2011/2012 to 2.6 MMT in 2017/2018 (Figure 8).

Sorghum for industrial consumption is mainly used for brewing liquor (Baijiu). So the change of liquor production directly affects the change of sorghum industrial demand.

The change of liquor production in China can be roughly divided into five historical stages: Firstly, the liquor industry developed slowly from 1949 to 1978, and its output increased from 0.11 MMT to 1.44 MMT. Secondly, the liquor industry entered a phase of rapid growth from 1978 to 1996, and its output increased from 1.44 MMT to 8.01 MMT. Thirdly, the liquor industry entered a cold winter period from 1997 to 2003, and its output declined from 7.82 MMT to $3,135,000 \mathrm{kl}$ (from 2003, the unit of liquor production in China has changed from "10,000 tons" to " $10,000 \mathrm{kl}$ ") [15]. Fourthly, the liquor industry entered the golden ten-year development period from 2003 to 2012, and its output increased from 3,313,500 kl to 15,316,000 kl; Fifthly, since 2013, influenced by the national policy of restricting public consumption and prohibiting alcohol consumption, the development of the liquor industry has entered a period of deep adjustment, and it began to recover in 2016. The output of the liquor industry increased from $12,262,000 \mathrm{kl}$ in 2013 to $13,583,600 \mathrm{kl}$ in 2016 . Due to the adjustment of official statistics in 2017, the output of the liquor industry reached 11,981,000 kl, declining by $6.86 \%$ compared with 2016 (Figure 9). According to the data of the China Business Industry Research Institute, it is estimated that the liquor production in China will reach 13,186,000 kl in 2018. Guizhou, one of the main regions of liquor production, plans to produce $800,000 \mathrm{kl}$ of liquor by 2020 , $75.70 \%$ more than that of 2017 . The demand increase of the liquor industry is in a slow period, with an average annual growth rate of no more than $9 \%$. So it can be estimated that by 2020 the liquor production will recover to the level of 2017. The predicted value in 2018 is suggested to be presented in Figure 9. 


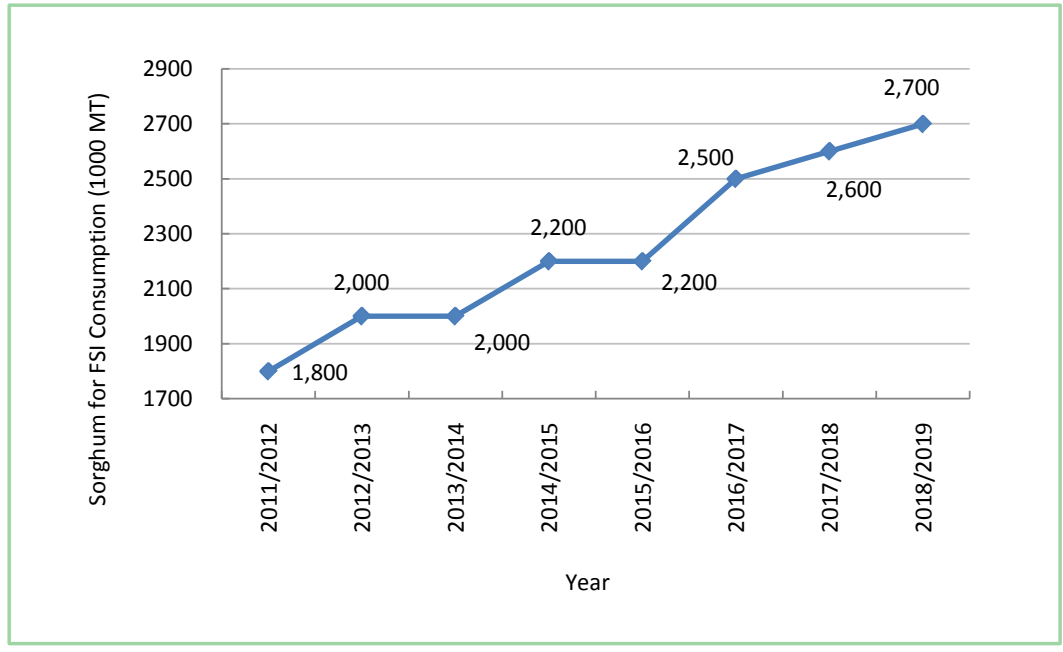

Figure 8. Sorghum for FSI consumption in china. Source: USDA.

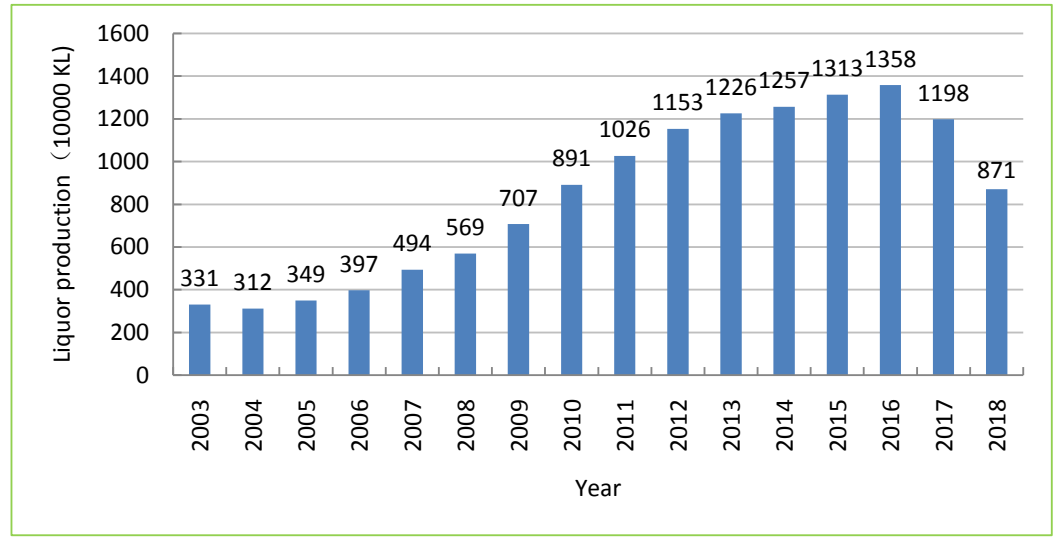

Figure 9. Liquor (Baijiu) production in China. Source: http://www.chyxx.com/industry/201812/698323.html, 12-10-2018; * Predicted value.

In general, 1 ton of sorghum can be brewed into $0.48-0.53$ tons of liquor. If these liquors were brewed using sorghum, 2.40 million tons of sorghum would be needed, accounting for about $60 \%$ of sorghum domestic production. Because liquor is also made from corn and barley, the demand of sorghum for industrial consumption will be lower than 2.40 million tons.

At present, wheat and corn are the main raw materials of ethanol fuel in China. The production of ethanol fuel in China reached 2.58 million tons in 2016. According to the ratio of 1:3.30, it needs about 8.51 million tons of corn. China plans to develop the scale of bioenergy production to 15 million tons by 2020 . About 2.67 million hectare of sweet sorghum would need to be planted if 10 million tons of ethanol were produced by only sweet sorghum [8]. This is unrealistic, obviously. According to the estimation of sorghum planting area in China in 2020, 40 million tons of sorghum straw can be produced, which can produce 2.49 million tons of ethanol. 


\subsubsection{Sorghum for Feed}

The biggest change in sorghum consumption in the past five years is feed consumption. According to the data of USDA, sorghum for feed consumption increased from 1.20 MMT in 2012 to 10.7 MMT in 2014, then, declined to 2.70 MMT in 2018 (Table 4). Data from "Report on Operation Situation and Development Analysis of Sorghum Industry in China" showed that the share of sorghum for feed consumption has fallen sharply by $53 \%$, because the decrease of corn price led to the reverse substitution of sorghum feed. Price of corn fell from 340 dollars/MT in 2015 to 241 dollars/MT in 2017 and sorghum for feed consumption declined from 10.70 MMT to 5.80 MMT over the same period (Table 4).

A factor that affects the amount of sorghum for feed consumption is the price of corn. From the data of Table 4, feeding demand of sorghum could no longer be simply calculated by cross-elasticity of demand, except from 2015 to 2017. Sorghum for feed consumption came mainly depends on imported sorghum. Imported sorghum accounted for was more than $90 \%$ of sorghum feed consumption in 2015 and 2016. From 2015 to 2017, sorghum imports decreased by $31.30 \%$ annually. Specifically, on April 17, 2018, China announced an import duty of $178.60 \%$ on the value of U.S. sorghum imports, to be applied the following day [16]. Since July 6 , China has imposed a $25 \%$ import tariff on agriculture products including sorghum from the U.S. These trade policies led to a reduction in sorghum imports from 5.06 MMT in 2017 to 3.62 MMT in 2018 by September. Imported sorghum decreased a total of $0.60 \mathrm{MMT}, 17.13 \%$ less than the same period in the last year. According to this ratio (31.30\%), China's sorghum imports will reduce to 1.64 MMT by 2020 .

Table 4. Sorghum for feed and ratio of price of sorghum/corn.

\begin{tabular}{|c|c|c|c|c|c|c|c|}
\hline Year & 2012 & 2013 & 2014 & 2015 & 2016 & 2017 & 2018 \\
\hline Sorghum for Feed $(1000 \mathrm{MT})^{1}$ & 400 & 1200 & 4800 & 10,700 & 8800 & 5800 & 5200 \\
\hline Sorghum Imports $(1000 \mathrm{MT})^{1}$ & 84 & 631 & 4161 & 10,162 & 8284 & 5209 & 4300 \\
\hline $\begin{array}{l}\text { Proportion of Imported } \\
\text { Sorghum in Feed (\%) }\end{array}$ & 21.00 & 52.58 & 86.69 & 94.97 & 94.14 & 89.81 & 82.69 \\
\hline Sorghum Imports $(1000 \mathrm{MT})^{2}$ & 86.60 & 1078 & 5776 & 10,699 & 6648 & 5057 & $3620^{6}$ \\
\hline $\begin{array}{l}\text { Price of Imported Sorghum } \\
(\text { Dollars per MT) })^{3}\end{array}$ & 269.20 & 342.44 & 283.54 & 277.69 & 214.84 & 202.94 & $244.33^{5}$ \\
\hline Price of Corn (Dollars per MT) ${ }^{4}$ & 355.48 & 357.08 & 377.37 & 340.29 & 260.97 & 240.85 & $267.10^{6}$ \\
\hline Ratio of Price of Sorghum/Corn & 0.76 & 0.96 & 0.75 & 0.82 & 0.82 & 0.84 & 0.91 \\
\hline Cross-Price Elasticity of Demand & - & - & - & 1.80 & 1.46 & 1.34 & - \\
\hline
\end{tabular}

${ }^{1}$ Source: USDA, 2012-2018 refers to 2011/2012-2017/2018; ${ }^{2}$ Source: General Administration of Customs, P.R. China; ${ }^{3}$ Source: Calculation based on quantity and value of imported sorghum; ${ }^{4}$ Source: Calculation based on the data from http://price.cngrain.net/sinoprice/LPIndex.aspx?id=2; ${ }^{5}$ Data up to September 2018; 6Data up to December 16, 2018. 
Research on sorghum feed demand is rare due to the lack of domestic sorghum consumption data. Most studies predicted feed grain and corn. Yang et al. (2017) predicted that the demand of feed grain will reach 151.42 MMT by 2020 [13]. Corn for feed consumption will reach 115.41 MMT by 2020 [13]. Liu et al. (2012) calculated that the demand of feed grain will reach 185.86 MMT, including 124.71 MMT for corn, 34.21 MMT for rice, and 26.93 MMT for wheat, based on the proportion of raw grains consumed by feed grains, $67.10 \%$ of corn, $18.41 \%$ of rice and $14.49 \%$ of wheat [17]. Ran et al. (2017) predicted that the demand of feed grain will reach 215.96 MMT by 2025 [1]. Therefore, projections of demand feed grain differ in every study. This is to be expected because different assumptions, research methods, and data are used [18]. In any case, the trends and directions of these predictions are consistent. We use these predictions to estimate the feed demand of sorghum because the feed demand of sorghum is mainly the substitution of corn demand. With China eliminating its temporary reserve program of corn and disposing of its stocks immediately, Chinese produced corn price would go below the sorghum producer price. According to the energy ratio, when the price difference between sorghum and corn is more than $5 \%$, the ratio of imported sorghum price to domestic corn price is below $0.95^{4}$, and sorghum can be used as a substitute for corn [4]. The ratio of producer price of sorghum/corn will be more than 0.95 in 2020 in different scenarios, according to Wang's predictions [19]. The results implied that the domestic sorghum, which has been considered as a low-cost substitute for corn for feed grain use, may not have a price advantage in the future [19]. Sorghum for feed consumption will continue to decline according to Wang [19] and others. From Table 4, sorghum for feed consumption declined from 10.70 MMT in 2015 to 5.20 MMT in 2018, the average annual decline was $21.40 \%$ [19]. According to this ratio, sorghum for feed demand will decline to $3.20 \mathrm{MMT}$ in 2020.

\section{Conclusion}

The conclusion is that taking into account China's current Agricultural Structure Adjustment policy, in the expected circumstances, China's domestic supply for sorghum will continue to increase a rate largely comparable to the rate of increase in the past few years. Yet due to " $95 \%$ self-sufficiency" program, the increase is limited and the production of sorghum will reach about 4.00 MMT in 2020. China's domestic demand for sorghum will continue to decline due to a low-cost substitute for corn for feed grain use.

\section{Conflicts of Interest}

The authors declare no conflicts of interest regarding the publication of this paper.

${ }^{4}$ Source: http://www.yumi.com.cn/html/2014/06/20140616233528155688.html, 2014-06-16. 


\section{References}

[1] Ran, J. and Wang, J.M. (2017) Prediction and Analysis of Feed Grain Demand Based on Feed Demand in China. Journal of China Agricultural University, 5, 190-198.

[2] Wang, M.H. (2012) Analysis on the Supply and Demand Situation of Feed Grain in China. The World of Survey and Research, 2, 24-26.

[3] Wei, J.Y., Zhang, B.Y., Feng, Y., et al. (2014) Application of Imported Sorghum in Pig and Chicken. Guangdong Feed, 5, 39-40.

[4] Feng, L.C. (2015) Analysis on Normalization Trend of Imported Raw Material for Feed in China. Industry Economy, 10, 110-112.

[5] Wang, H.Y. and Malaga, J. (2016) Potential Scenarios for China's Future Grain Sorghum Excess Demand. Agricultural \& Applied Economics Association Annual Meeting, Boston, 31 July-2 August 2016.

[6] Yin, Z.H. and Hui, F.P. (2012) Planting, Processing and Utilization of Sorghums in Ancient China. Journal of Arid Land Resources and Environment, 2, 167-173.

[7] Lu, Q.S., Zou, J.Q., Zhu, K. and Zhang, Z.P. (2009) Discussion on the Development of Sorghum Industry in China-Superiority Regions of Sorghum Production. Rain Fed Crops, 2, 78-80.

[8] Lu, Q.S., Zhang, Z.P., Lu, F. and Wang, Y.Q. (2009) Discussion on the Development of Sorghum Industry in China-Development of Sweet Sorghum Energy Industry. Rain Fed Crops, 4, 246-250.

[9] Lu, Q.S., Zou, J.Q. and Shi, Y.S. (2009) Discussion on the Development of Sorghum Industry in China-Development of Sorghum Feed Industry. Rain Fed Crops, 5, 313-317.

[10] Li, D.P. and Wang, X.H. (2010) A Brief Analysis of the Problem of Feed Grain. Chinese Feed, 21, 4-6.

[11] Zhao, L.Y. (2008) New Development Trend of Miscellaneous Grain Industry. Beijing Agriculture, 6, 51.

[12] Li, J., Wu, P.Z., Li, M.R., et al. (2007) Research Progress and Development Trend of Energy Plants. Natural Hybridization, 1, 21-24.

[13] Yang, Y.T. and Qin, F. (2017) China's Regulation Policy Choice of Feed Grains Supply and Demand and Import Rebalancing during the 13th Five-Year Plan Period. Economic Review, 2, 104-109.

[14] Chai, Y. (2017) Current Situation of Minor Grain Production and Industrial Development Countermeasures in China. Newspaper of Hebei Science and Technology.

[15] Yang, L. and Zhang, X.B. (2018) Review and Consideration on the History of Chinese Liquor. Liquor Making, 11, 9-12.

[16] Hansen, J., Marchant, M.A., Zhang, W. and Grant, J. (2018) Upheaval in China's Imports of U.S. Sorghum. AAEA. 2nd Quarter, 1-8.

[17] Liu, J.Z. and Tang, Q.P. (2012) Feeding Grains Prediction Based on Trend of Diet Structure Changes. Journal of Anhui Agricultural Sciences, 30, 14753-14756.

[18] Zhou, Z.Y., Tian, W.M. and Malcolm, B. (2008) Supply and Demand Estimates for Feed Grains in China. Agricultural Economics, 39, 111-122. https://doi.org/10.1111/j.1574-0862.2008.00319.x

[19] Wang, H.Y. (2017) China's Grain Sorghum Import Demand: Measuring the Effect of Policies on Price Relationships and Future Trends. Texas Tech University, Lubbock. 